\title{
Analysis of cell-cell bridges in Haloferax volcanii using Electron cryo-tomography reveal a continuous cytoplasm and S-layer
}

\author{
Shamphavi Sivabalasarma ${ }^{1,3}$, Hanna Wetzel ${ }^{1}$, Phillip Nußbaum ${ }^{1}$, Chris van der Does ${ }^{1}$, \\ Morgan Beeby ${ }^{2}$ and Sonja-Verena Albers ${ }^{1,3, *}$

\footnotetext{
${ }^{1}$ Molecular Biology of Archaea, Institute of Biology II, Faculty of Biology, University of Freiburg, Freiburg, Germany.

2 Department of Life Sciences, Imperial College London, London, United Kingdom.

${ }^{3}$ Spemann Graduate School of Biology and Medicine, University of Freiburg, Freiburg, Germany.
}

*Correspondence: Sonja-Verena Albers, sonja.albers@biologie.uni-freiburg.de

Halophilic archaea exchange DNA and proteins using a fusion-based mating mechanism. Scanning electron microscopy previously suggested that mating involves an intermediate state, where cells are connected by an intercellular bridge. To better understand this process, we used electron cryotomography and fluorescence microscopy to visualize cells forming these intercellular bridges. Electron cryo-tomography showed that the observed bridges were enveloped by an S-layer and connected mating cells via a continuous cytoplasm. Macromolecular complexes like ribosomes and unknown thin filamentous helical structures were visualized in the cytoplasm inside the bridges, demonstrating that these bridges can facilitate exchange of cellular components. We followed formation of a cell-cell bridge by fluorescence time-lapse microscopy between cells at a distance of $1.5 \mu \mathrm{m}$. These results shed light on the process of haloarchaeal mating and highlight further mechanistic questions.

\section{Introduction}

Horizontal gene transfer is fundamental to archaeal and bacterial evolution. The diverse mechanisms of horizontal transfer, however, remain incompletely understood (Wagner, Whitaker, Krause, Heilers, Van Wolferen, et al. 2017). These mechanisms include uptake of DNA via natural transformation, transfer of conjugative plasmids, transduction, uptake of DNA via membrane vesicles and cell fusion hybrids (Wagner, Whitaker, Krause, Heilers, van Wolferen, et al. 2017). Members of Euryarchaeota, Pyrococcus furiosus and Thermococcus kodakaraensis are naturally competent taking up linear and circular DNA (Lipscomb et al. 2011; Sato et al. 2005). Transfer of conjugative plasmids was described first in Sulfolobales by the isolation of the first archaeal conjugative plasmid in 1995 (Prangishvili et al. 1998; Schleper et al. 1995; Stedman et al. 2000). Interestingly, analysis of the genome of Sulfolobales revealed the insertion of proviral DNA from Sulfolobus spindle-shaped virus 1 (SSV1) (Schleper, Kubo, and Zillig 1992). SSV1 stays integrated in archaeal genomes and producing viral particles budding from the cells for the transfer of viral DNA (Quemin et al. 2016). Methanococcus voltae PS produces viral particles named "voltae transfer agent" (VTA) which can carry chromosomal fragments instead of viral DNA (Bertani 1999; Eiserling et al. 1999; Lang, Zhaxybayeva, and Beatty 2012). Similarly to VTA, Thermococcales release membrane vesicles packed with chromosomal and plasmid DNA for the exchange of genetic material (Soler et al. 2008). Members of Sulfolobus spp. can exchange DNA upon UV-induced DNA damage allowing for DNA repair using homologous recombination (Ajon et al. 2011; Fröls et al. 2008). Cell aggregates are formed mediated by UVinduced pili (Ups-pili) and the crenarchaeal exchange of DNA system (Ced-system) is activated (Ajon et al. 2011; Fröls et al. 2008; Fröls, White, and Schleper 2009). Using the Ups-pili cell-cell contact is established and DNA is exchanged (Van Wolferen et al. 2016). Remarkably the exchange is species-specific possibly being mediated by the degree of $\mathrm{N}$-glycosylation of Ups-pili (van Wolferen et al. 2020). Finally bidirectional gene transfer occurs in haloarchaea via cell fusion 
bioRxiv preprint doi: https://doi.org/10.1101/2020.09.30.320622; this version posted September 30, 2020. The copyright holder for this preprint (which was not certified by peer review) is the author/funder, who has granted bioRxiv a license to display the preprint in perpetuity. It is made available under aCC-BY-NC 4.0 International license.
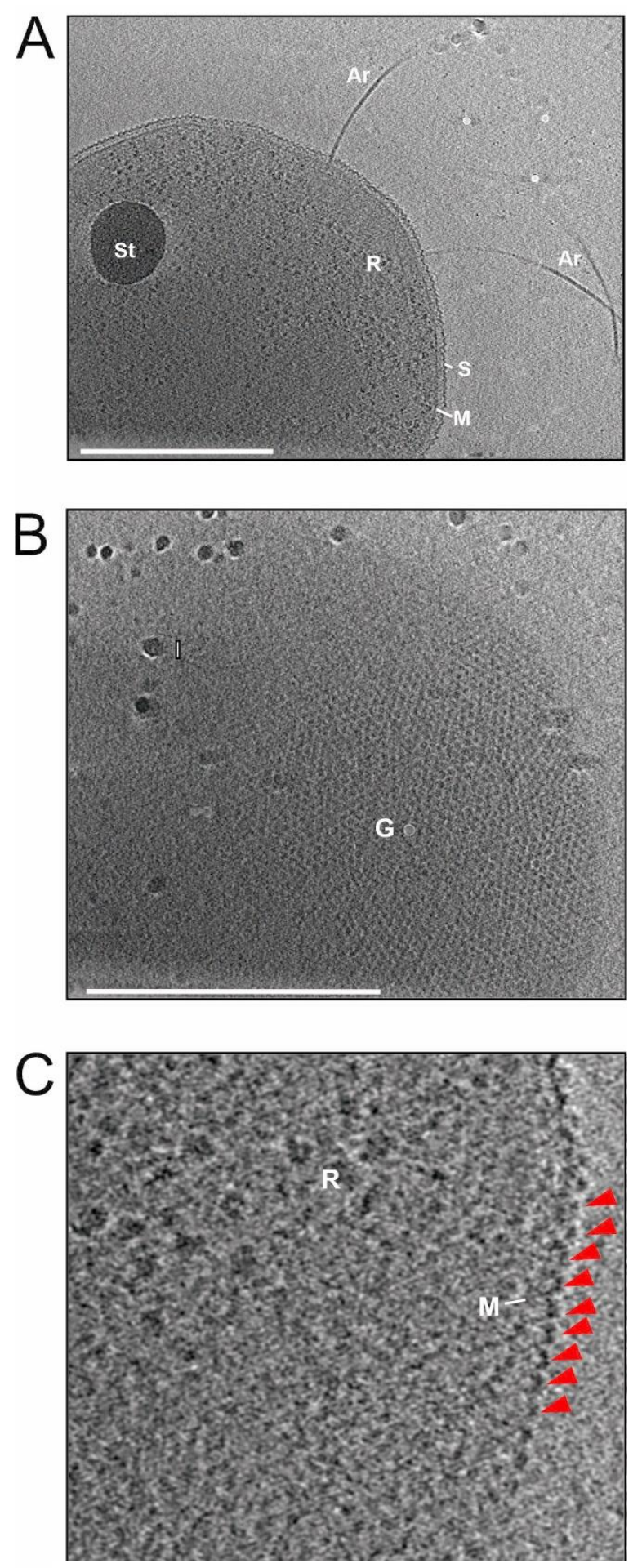

(Mevarech and Werczberger 1985; Rosenshine, Tchelet, and Mevarech 1989).

Here, the bidirectional DNA transfer through cell fusion in haloarchaea is further elucidated. In the 1980s, it was described that mixing of two different auxotrophic strains of the halophilic euryarchaeon Haloferax volcanii, resulted in prototrophic recombinant cells. The mating frequency was determined in the presence of DNase to rule out natural transformation and was $10^{-6}$ (Mevarech and Werczberger 1985). It was proposed that transfer of genetic material occurred via an uncharacterized fusion-based mating mechanism (Mevarech and Werczberger 1985). Remarkably, the transfer of DNA in $\mathrm{H}$. volcanii is bidirectional without a specific donor or recipient and since mating and subsequent DNA exchange has been observed between the geographically distant species $H$. volcanii and $H$. mediterranei, it is not necessarily species specific (Naor et al. 2012). It was observed that two Haloferax volcanii cells can fuse to form a hybrid state (Naor et al. 2012; Naor and Gophna 2013). In this state, large chromosomal DNA fragments are exchanged and after recombination followed by cell separation, this results in genetic hybrids of the parents (Naor et al. 2012; Naor and Gophna 2013). CRISPR spacers matching chromosomal genes, including housekeeping genes, are also exchanged between species (Turgeman-Grott et al. 2019). Strikingly, mating frequency depends on factors that impact the cell surface such as external salt concentration and $\mathrm{N}$ glycosylation of the S-layer (Shalev et al. 2017). Defects in the N-glycan of S-layer proteins significantly reduce mating frequencies, suggesting an important role for S-layer glycosylation in initiation of cell-cell interaction and cell fusion (Shalev et al. 2017). Scanning electron micrographs of $H$. volcanii have suggested the formation of intermediate intercellular bridges prior to cell fusion (Rosenshine, Tchelet, and Mevarech 1989). These cell-cell bridges might allow for an exchange of genetic material and drive cell fusion (Naor and Gophna 2013). Exchange of genetic material has only been observed on solid media in previous studies, prompting questions about the mechanisms involved in mating. Formation of possible cell-cell bridges between cells has also been observed in other archaeal lineages, such as members of Sulfolobales (Schleper et al. 1995), Thermococcales (Kuwabara et al. 2005) and even between Nanoarchaea and Thermoplasmatales (Comolli and Banfield 2014). Formation of cell-cell bridges was also

Figure 1: Electron cryo microscopy and subtomogram slices of $H$. volcanii (A) A slice through the reconstructed tomogram of $H$. volcanii. The subtomographic slice reveals the cells filled with ribosomes $(\mathrm{R})$ and a possible storage granule (St). The cells are enveloped by the cytoplasmic membrane $(\mathrm{M})$ and a S-layer (S). From the cells, the archaellar motility system, the archaellum, extends (Ar). Scale bare is $500 \mathrm{~nm}$. (B) Extracted subtomographic slice, showing the top view of the cell. The cell body is covered by the hexagonal arranged Slayer lattice. Gold fiducial (G) and ice crystal (I) contaminations are indicated. Scale bar is $500 \mathrm{~nm}$. (C) A magnified tomographic slice from (A) showing the characteristic dome-like shape the arranged S-layer protein indicated by a red arrow. Scale bars in $100 \mathrm{~nm}$. 

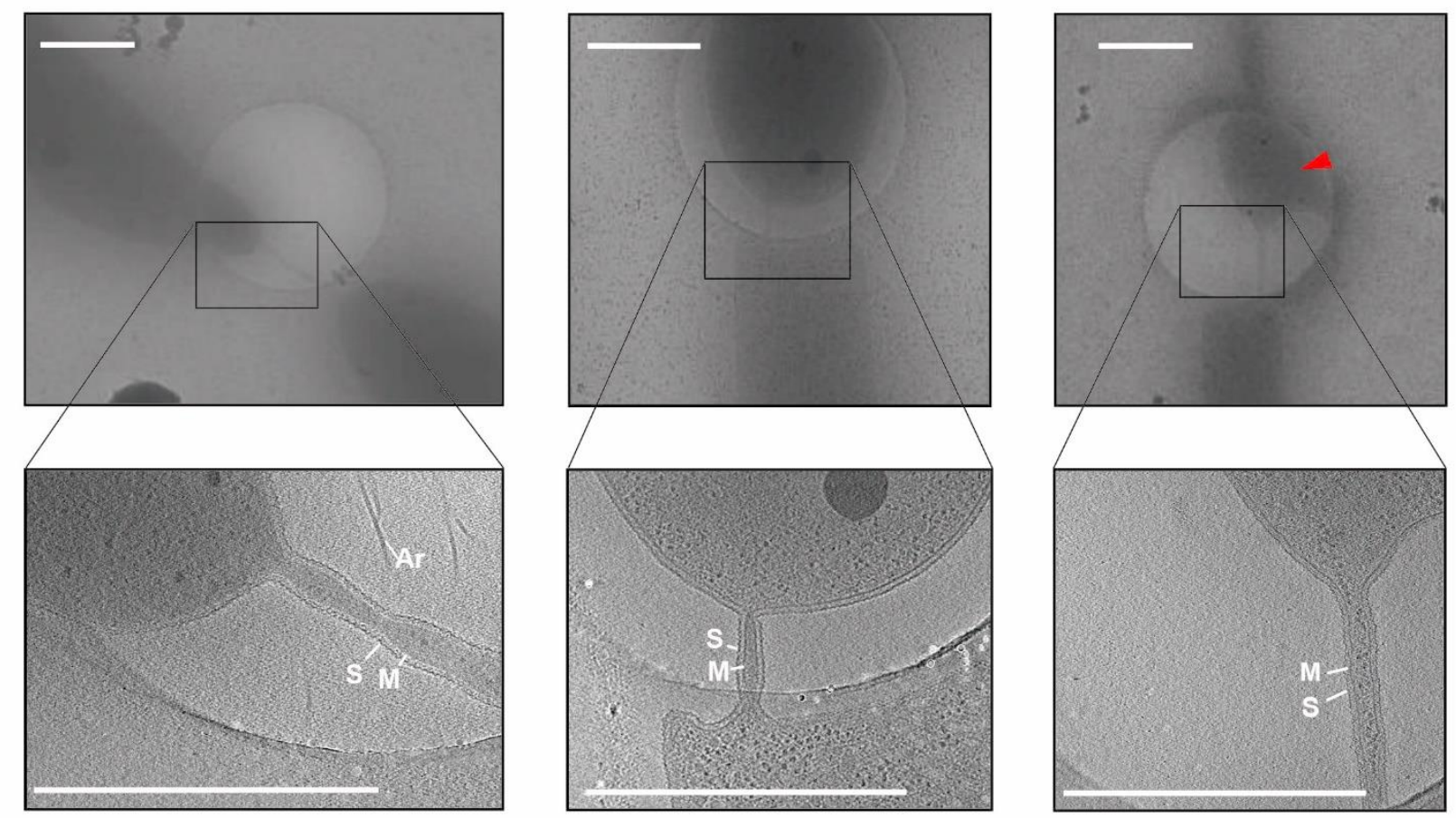

Figure 2: Electron cryo microscopy and tomographic slices of cell-cell bridges in $\boldsymbol{H}$. volcanii. Low magnification cryo micrographs of cell-cell bridges targeted for cryoET (upper panels) with the corresponding tomographic slice from a reconstructed tilt series (lower panels). The electron cryo micrographs as well and the corresponding slice through tomograms depict the variety in shape, length and width of the cell-cell bridges. The right panel shows a partially ruptured cell indicated by a red arrow. Scale bars are $1 \mu \mathrm{m}$. The cytoplasmic membrane (M), the S-layer (S), and Archaella (Ar) are indicated.

reported in bacterial species. These nanotubes are enveloped by a membrane layer and build a bridge between two neighboring bacterial cells allowing an exchange of cytoplasm (Baidya et al. 2018; Dubey and Ben-Yehuda 2011).

To better characterize the mechanism of horizontal gene transfer by fusion in $\mathrm{H}$. volcanii, we used electron cryotomography (cryoET) to preserve whole cells in a frozen hydrated state. We identified and imaged cellcell bridges connecting the cytoplasms of pairs of cells grown in liquid media. Tomograms revealed that two mating cells shared a continuous membrane, a continuous S-layer and had continuous connected cytosols. Strikingly, macromolecular structures were detected in the cell-cell bridges likely to be ribosomes. Fluorescence time-lapse microscopy of $H$. volcanii cells with fluorescently stained S-layers showed how cells established an intercellular bridge as an intermediate state prior to cell fusion.

\author{
Results \\ Whole cell in situ electron cryo-tomography \\ captures cell-cell bridges between two $H$. volcanii \\ cells
}

To investigate the structure of the cell-cell bridges in $\mathrm{H}$. volcanii, whole-cell electron cryo-tomography (cryoET) was used. CryoET offers the possibility to image cells in their native environment in a near-native frozenhydrated state to macromolecular resolutions. Cryomicrographs of vitrified $H$. volcanii cells grown in liquid medium were acquired. The initial tomograms showed archaellated cells with a possible storage granule as well as ribosomes in the cytoplasm (Figure 1). All detected cells were enveloped by a continuous paracrystalline and proteinaceous surface layer (Slayer) over the membrane (Figure 1). In $\mathrm{H}$. volcanii, the S-layer consist of one highly glycosylated protein that is secreted and lipid anchored to the membrane (Kessel et al. 1988; Sumper et al. 1990). The S-layer protein self-assembles to a 2D-lattice around the cell acting as a molecular sieve, involved in cell recognition and cell shape maintenance (Sára and Sleytr 2000; Sleytr et al. 2014). Strikingly, S-layer proteins could be detected, arranged in a hexagonal lattice around the cell similarly as reported in an early study (Figure 1B) (Kessel et al. 1988). Upon closer investigation of a subtomogram slice, the dome shape morphology formed by S-layer proteins can be identified (Figure 1C) (Kessel et al. 1988). The thickness of the S-layer was determined by measuring the distance from the membrane to the S-layer protein. The average 
bioRxiv preprint doi: https://doi.org/10.1101/2020.09.30.320622; this version posted September 30, 2020. The copyright holder for this preprint (which was not certified by peer review) is the author/funder, who has granted bioRxiv a license to display the preprint in perpetuity. It is made available under aCC-BY-NC 4.0 International license.

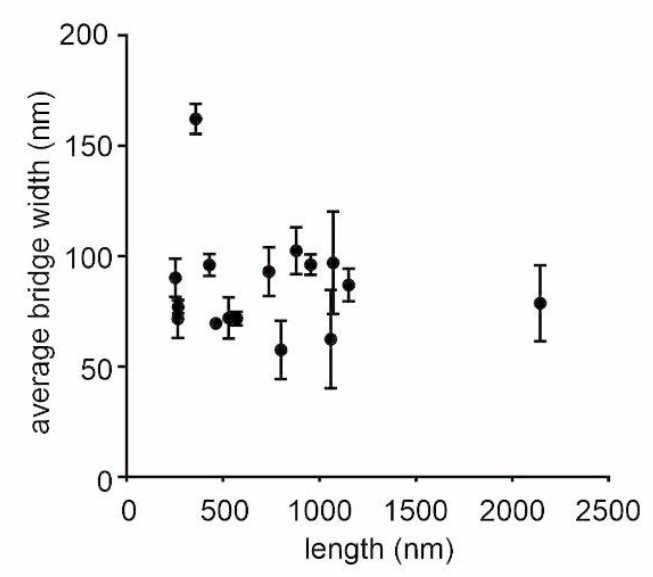

Figure 3: Determination of length and width of cell-cell bridges. (A) Scatter plot of length against the corresponding average width of cell-cell bridges. Only cell-cell bridges were considered that connected two cells together.

thickness was determined to $20.4 \pm 2.7 \mathrm{~nm}$ (Supplementary Table S1).

Interestingly, cryoET allowed the observation of several cells in a hemifusion state connected via cellcell bridges (Figure 2, upper panels). In total, out of 280 collected tilt series 20 tilt series of cell-cell bridges were acquired with a magnification sufficient to focus on the intercellular bridges (Figure 2, lower panels). As well as cell-cell bridges between intact cells (Figure 2, left panels), we observed cell bridges between intact and broken cells (Figure 2, middle panels) and disrupted cell bridges. These broken cells and disrupted bridges were probably ruptured during the blotting procedure. A representative tilt series is shown in supplementary movie S1.

We measured the widths and lengths of cell-cell bridges. The width was measured over the length of the cell-cell bridge and average width of each cell-cell bridge was determined (Figure 3, Table S1). For determination of the length, only the cell-cell bridges were considered that connected two cells as shown in Figure 2 (left and middle panel). The width varied from $57-162 \mathrm{~nm}$ and the length varied from 253-2144 nm (Figure 3, Table S1). The scatter plot and histogram (Figure 3 ) shows that most cell-cell bridges have a width up to $100 \mathrm{~nm}$ with a maximal length of $1 \mu \mathrm{m}-1.2$ $\mu \mathrm{m}$ indicating that cells might need to be within $\sim 1.2$ $\mu \mathrm{m}$ for the formation of cell-cell bridges to occur. No relation between length and diameter could be detected.

\section{Cell-cell bridges are surrounded by a continuous S-layer and connect the cytoplasms of two cells}

Closer investigation of the cell-cell bridges showed that these bridges connected the cytoplasms of the two cells. The connected cytoplasm was surrounded by a continuous cytoplasmic membrane and a continuous S-layer. (Figure 4). Since the cytoplasms of the two cells are connected, this would allow exchange of cytoplasmic materials between two cells. Indeed, we saw large macromolecular complexes consistent with the size, shape, and density of ribosomes within the tubular cell-cell bridges (Figure 4, Movie S1), suggesting that high molecular weight complexes are exchanged between mating cells. Next to the
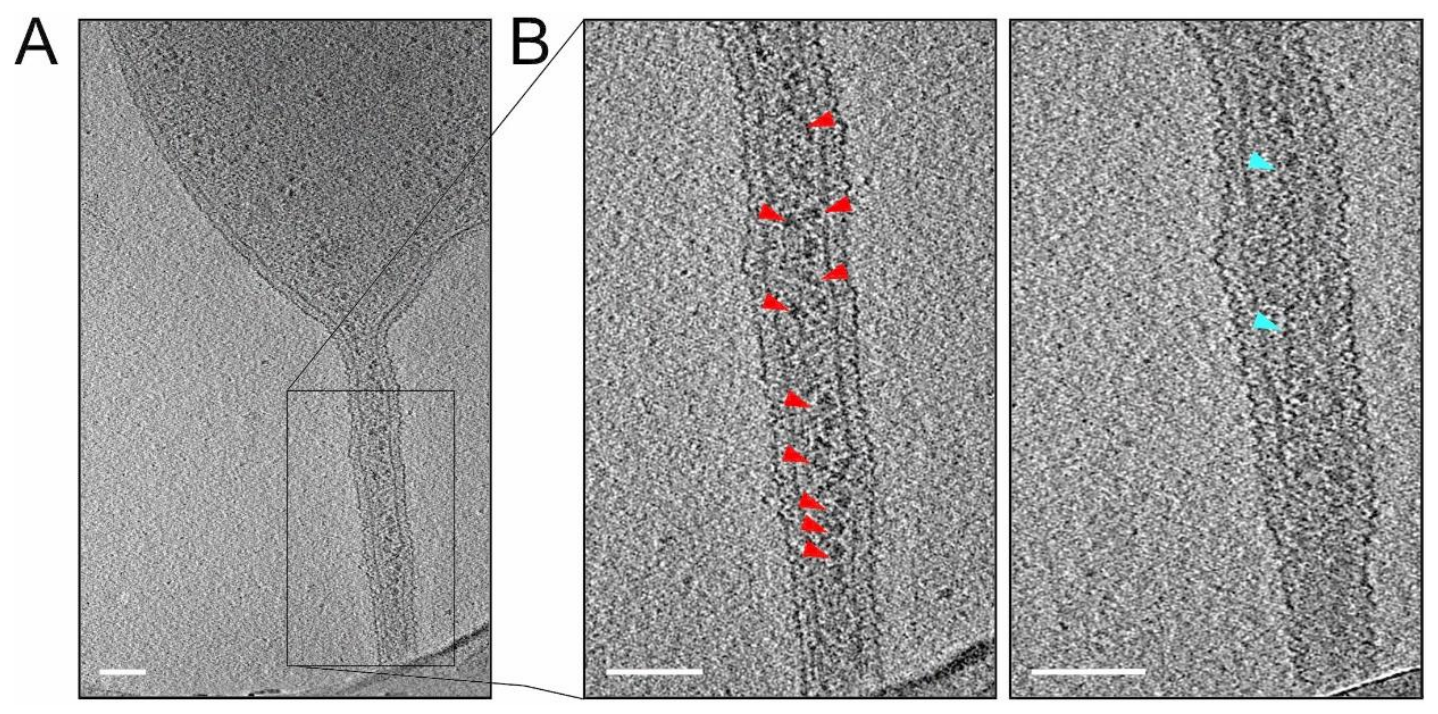

Figure 4: Detection of macromolecular complexes in cell-cell bridges. (A) A micrograph of a targeted cellcell bridge shows the presence of ribosomes in the cell-cell bridge (as indicated by red arrows). (B) The left panel shows the magnified tomographic slice of the cell-cell bridge and shows the ribosomes arranged in a chain-like manner (as indicated by red arrows). The right panel shows another slice of the selected cell-cell bridge showing a long filamentous structure inside the cell-cell bridge (as indicated by blue arrows). Scale bars are $100 \mathrm{~nm}$ 
ribosomes also unknown thin filamentous helical structures of $199 \pm 18 \mathrm{~nm}$ long and $9.0 \pm 2.3 \mathrm{~nm}$ wide (Figure 4B, Movie S1) were observed in the one of the analyzed cell-cell bridge. The function and the proteins that form the thin filamentous helical structures are unclear although we speculate they may be cytomotive filaments to drive cytoplasmic exchanges.

In vivo observation of the formation of an intercellular $\boldsymbol{H}$. volcanii cell-cell bridge

The tomograms showed that intercellular bridges are encapsulated by an S-layer. To follow the formation of a cell-cell bridge using time-lapse fluorescence microscopy, the cells were incubated with the Alexa Fluor $488 \mathrm{NHS}$ Ester and the cells were followed over a period of 16 hours. As expected, the cells were mainly fluorescently labelled on the outside. Comparison of the proteins which were labelled with the fluorescent probe in the total cell extract with isolated S-layers showed that, next to the S-layer protein, also several other proteins were labelled (Supplementary figure 1). Several experiments were conducted where over 16 hours every $30 \mathrm{~min}$ fluorescent and phase contrast images were acquired. In one of these experiments, the formation of a cellbridge was observed. Notably, after five hours of incubation, one thin fluorescent connection between two cells was detected that can be identified as a de

$\mathrm{Oh}$
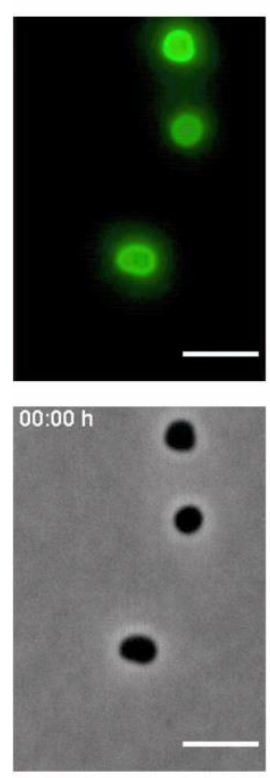

$1.5 \mathrm{~h}$
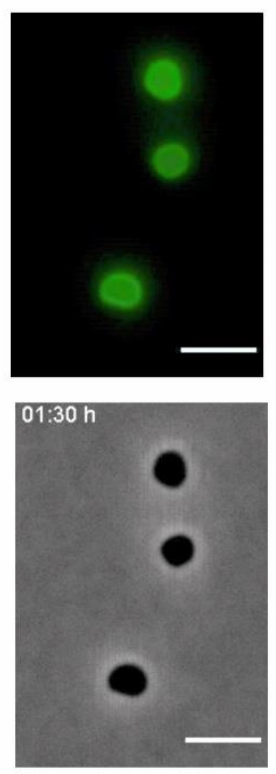

$3 \mathrm{~h}$
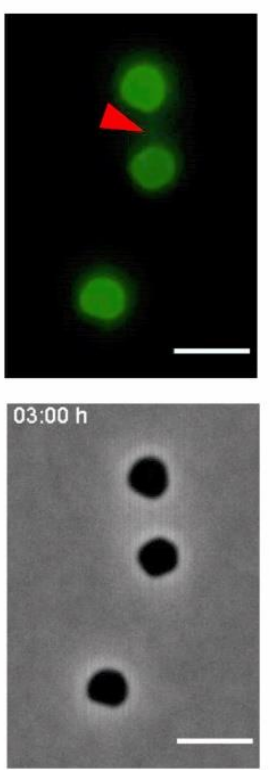

novo formed cell-cell bridge. (Figure 5, Movie S2). The time lapse movie shows fluorescent cells with increasing cell size due to an unknown cell division defect where a fluorescent septum is formed between two adjacent cells which do not separate. This is sometimes observed during these experiments and is most likely unrelated to the observed cell-cell bridge. Between the 2:30 and 3:00 hr time points a full cell-cell bridge is formed. Remarkably, the cell-cell bridge is formed between two cells at $1.5 \mu \mathrm{m}$ distance without any initial direct contact, suggesting that cell-cell bridge formation is an active process. CryoET showed that shortly after cell-cell bridge formation the cytoplasms are most likely connected and transfer between the two cells can occur through the cell-cell bridges. It was not possible to determine whether the cell-cell bridge is formed from one or from both cells. After 7.5 hours, the length of the cell-cell bridge is decreasing indicating a contraction to bring both cells in close proximity (Figure 5). The cell-cell bridge was maximally $1.5 \mu \mathrm{m}$ long, growing shorter and thicker over time. Unfortunately, the in vivo formation of only one cell-cell bridge could be observed as cell-cell bridge formation, however, this is the first time that the formation of a cell-cell bridge could be observed in real time.

\section{Discussion}

Mechanisms of gene transfer are diverse in Archaea (Ajon et al. 2011; Allers 2011; Bertani 1999; Meile, Abendschein, and Leisinger 1990; Naor et al. 2012;

$4.5 \mathrm{~h}$
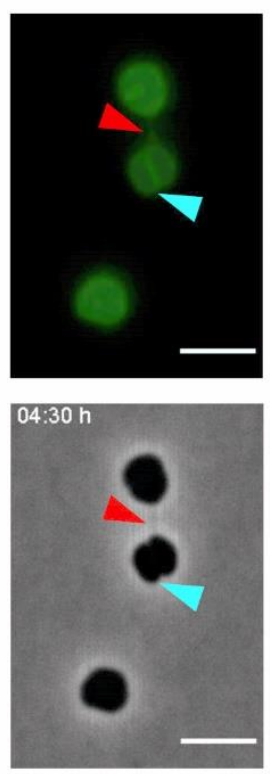

$6 \mathrm{~h}$
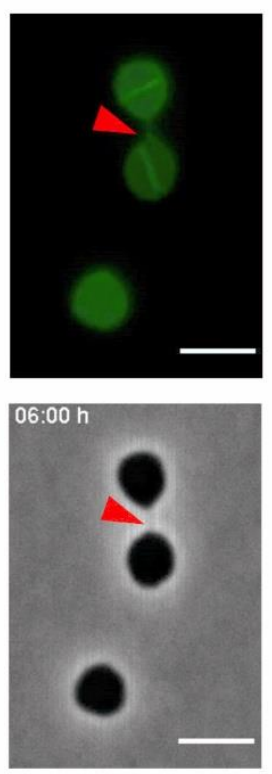

$7.5 \mathrm{~h}$
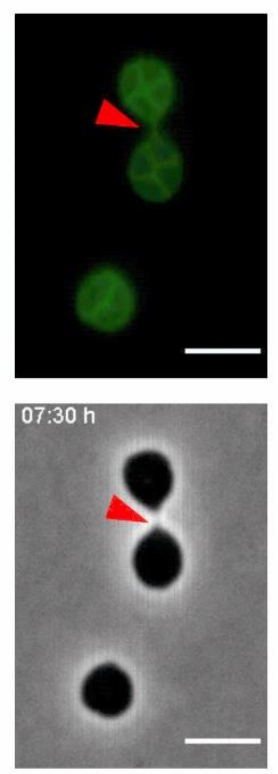

Figure 5: Formation of a cell-cell bridge followed by fluorescence microscopy. Time-lapse fluorescence images of AlexaFluor488 labeled $\mathrm{H}$. volcanii cells with the corresponding phase-contrast image. The fluorescence signal for the cell-cell bridge can be detected after $5 \mathrm{~h}$ and is indicated by a red arrow. In phase contrast, the cellcell bridge can be detected after $7 \mathrm{~h}$. Blue arrows indicate the septum formed between the cells due to a cell division defect. Scale bars are $4 \mu \mathrm{m}$. 
Prangishvili et al. 1998; Schleper et al. 1995; van Wolferen et al. 2013, 2020). In $H$. volcanii genetic transfer occurs in a bidirectional manner upon fusion (Mevarech and Werczberger 1985; Naor and Gophna 2013; Rosenshine, Tchelet, and Mevarech 1989) and it was proposed that the formation of cell-cell bridges may precede fusion as an intermediate state (Naor and Gophna 2013; Rosenshine, Tchelet, and Mevarech 1989).

Whole-cell cryoET enabled preservation and the study of cells in this intermediate bridged state, while timelapse fluorescence allowed for the observation of the formation of cell-cell bridges in real-time. Despite the high salinity of the cell cytoplasm and the media, electron cryo-tomograms gave a high resolution snapshot of the features of the cell-cell bridges in $H$. volcanii. However, only a limited number of cell-cell bridges could be studied. In contrast to the cell-cell bridges observed by Mevarech and Rosenshine on solid media, bridge formation and fusion events were recorded in liquid media, but in liquid media, these events occur most likely much less often than on solid media (Rosenshine, Tchelet, and Mevarech 1989). Furthermore, more cell-cell bridges would probably have been observed in an medium containing a higher salt concentration, as mating efficiency was shown to be higher at $3.4 \mathrm{M} \mathrm{NaCl}$ instead of the $2.2 \mathrm{M} \mathrm{NaCl}$ in the medium used (Shalev et al. 2017). However higher salt would reduce the clarity of electron micrographs.

Time-lapse fluorescence microscopy allowed for the observation of the de novo formation of a cell-cell bridge. This showed that cells are able to bridge the distance by the formation of a cell-cell bridge reaching to the adherent cell. The time-lapse fluorescence microscopy showed a cell-cell bridge that was formed over a distance of $1.5 \mu \mathrm{m}$ whereas the cryoET showed that most cell-bridges were shorter than 1-1.2 $\mu \mathrm{m}$, which demonstrates that cell-bridges with a length of $\sim 1 \mu \mathrm{m}$ can be easily formed. Full cell-cell bridge formation was observed within $0.5 \mathrm{hr}$, suggesting it is a relatively fast process (See movie S2 between 2:30 and 3:00 hrs). Indeed, a recent transcriptomic study showed that mating impacts genes involved in cell division and glycosylation. Strikingly, increased expression was detected for selfish genetic elements, restriction-modification system and CRISPR-Cas. These changes were detected in the first hours after transfer to a filter paper, indicating that mating efficiency is probably the highest 4 to $8 \mathrm{~h}$ after cell contact (Makkay et al. 2020). Since adherence must be the first step before fusion, cells may initially form an Slayer covered protrusion that detects the adherent cell and initiates formation of the cell-cell bridge. Indeed, glycosylation of the S-layer is crucial in intraspecies mating efficiency (Shalev et al. 2017). Significantly fewer fusion events were observed when neither tetranor pentasaccharides decorated the S-layer protein (Shalev et al. 2017). In Sulfolobales, N-glycosylation of UV-inducible pili is also crucial for species-specific UVinduced aggregation. Addition of different sugars to the media leads to decreased aggregation formation and ensuing reduced DNA exchange for DNA repair (van Wolferen et al. 2020). Similar to Sulfolobales, the Nglycan of a cell might be detected by surfaceexpressed receptor proteins for cell-cell recognition prior to cell-cell bridge formation.

All cell-cell bridges that were detected contained a connected S-layer and cytoplasm suggesting that the fusion of the cytoplasms occurs very shortly after the cell-cell bridge is formed. Time-lapse fluorescence microscopy indicated that the cell-cell bridge may shorten and widen for subsequent fusion of two cells (Figure 5, Movie S2). The electron cryo-tomograms revealed a variety in the size of cell-cell bridges possibly due to the different fusion states that were detected. Upon closer investigation of the cell-cell bridges, ribosomes and other complexes among which thin filamentous helical structures were detected indicating an exchange of cytoplasmic components.

Cell-cell bridges (nanotubes) have also been identified between members of bacterial species and also connect the cytoplasms of neighboring cells, but still little is known about how they are formed (Baidya et al. 2018; Dubey and Ben-Yehuda 2011). In Eukarya, cell fusion is a common mechanism, where gametes, myoblasts, or vesicles fuse to a partner or host cell. Fusion events are mostly mediated via fusogens (SNARE proteins) or fusexins in eukaryotic cells (Hernández and Podbilewicz 2017; Segev, Avinoam, and Podbilewicz 2018). By a controlled reorganization/folding of the fusogens or fusexins in the membranes of the mating cells, the high energy barrier to cell-cell fusion can be overcome (Segev, Avinoam, and Podbilewicz 2018). Although 2 DedA-like proteins related to the SNARE-associated Tvp38 proteins in eukaryotes have been identified in $\mathrm{H}$. volcanii, their role in the formation of cell-cell bridges remains unclear. Also the role and identity of the thin filamentous helical structures observed in the cell-cell-bridges remains unknown.

Here we have shown that $H$. volcanii can form cell-cell bridges which contain a continuous cytoplasm through which large molecular complexes like ribosomes can be exchanged. The formation of a cell-cell bridge was observed between two cells 1.5 um apart, suggesting this is an active process. These observations raise several new questions which should be addressed in future studies; How are these cell-cell bridges formed, do these cell-cell bridges grow from one or from both cells, how do the cell-cell bridges fuse?, and which proteins are required for the formation of the cell-cell bridges ?

\section{Material and Methods}

\section{Strains and growth conditions}

Growth of $H$. volcanii $\mathrm{H} 26$ and RE25 was performed as described previously (Allers et al. 2004; Esquivel and Pohlschroder 2014). The cells were grown in YPC medium with yeast extract, peptone and casamino 
acids (Bacto) or selective Casamino acid medium (CA medium) and CA medium supplemented with trace elements for selective growth as described (CAB) (Duggin et al. 2015).

\section{Electron cryo-tomography}

$H$. volcanii $R E 25$ was inoculated in $5 \mathrm{~mL} C A$ media plated supplemented with $1 \mathrm{~g} / \mathrm{l}$ thiamine and $0.1 \mu \mathrm{g} / \mathrm{L}$ biotin, $10 \mu \mathrm{g} / \mathrm{mL}$ uracil and $50 \mu \mathrm{g} / \mathrm{mL}$ tryptophan that was incubated at $42^{\circ} \mathrm{C}$ overnight. $5 \mu \mathrm{L}$ and $15 \mu \mathrm{L}$ of the pre-culture was inoculated in $20 \mathrm{~mL}$ CA media and incubated again at $42{ }^{\circ} \mathrm{C}$ overnight. At $\mathrm{OD}_{600}$ of 0.05 , the cells were harvested at $2000 \times \mathrm{g}$ for $20 \mathrm{~min}$ at 40 ${ }^{\circ} \mathrm{C}$. The pellet was dissolved in $1 \mathrm{~mL} \mathrm{CA}$ media and again pelleted at $2000 \mathrm{xg}$ for $10 \mathrm{~min}$ at $40^{\circ} \mathrm{C}$. The cell pellet was dissolved again in CA medium to a theoretical $\mathrm{OD}_{600}$ of 3 or 5 . The cells were mixed with BSA-coated $10 \mathrm{~nm}$ gold fiducial markers and $2.5 \mu \mathrm{L}$ of cells were applied to a freshly glow-discharged copper Quantifoil R2/2 grid (300 mesh). The vitrification of the grid was done using the Vitrobot Mark IV (FEI). The grid was blotted on the back using a repellent Teflon membrane and subsequently plunge-frozen in liquid ethane. Electron cryotomography was conducted with a FEI F20 (FEG) equipped with a Falcon II direct electron detector. A total cumulative electron dose of 120 e-/ $/ \AA^{2}$ was used per tilt series with -3 to $-6 \mu \mathrm{m}$ defocus using a tilt range of $\pm 53^{\circ}$ with $3^{\circ}$ increments and a pixel size of $8.28 \AA$. Data was acquired using Leginon (Carragher et al. 2000). Tomograms were reconstructed automatically using RAPTOR software and IMOD (Amat et al. 2008; Kremer, Mastronarde, and McIntosh 1996; Mastronarde 1997).

\section{S-layer staining}

H. volcanii $\mathrm{H} 26$ was inoculated in $5 \mathrm{~mL}$ CAB medium supplemented with $10 \mu \mathrm{g} / \mathrm{mL}$ uracil and grown overnight at $45^{\circ} \mathrm{C} .220 \mu \mathrm{L}$ were inoculated in $20 \mathrm{~mL}$ of the main culture which was grown overnight at $45^{\circ} \mathrm{C}$. The cells were harvested at $\mathrm{OD}_{600}=0.2$ at $1800 \mathrm{xg}$ for $10 \mathrm{~min}$ at $25^{\circ} \mathrm{C}$. The pellet was resuspended in $2 \mathrm{~mL}$ of buffered media and washed three times at $3400 \times \mathrm{xg}$ for $10 \mathrm{~min}$ at RT and resuspended in $500 \mu \mathrm{L}$ buffered media. The $\mathrm{pH}$ was adjusted to $\mathrm{pH} 8-8.5$ with $1 \mathrm{M}$ $\mathrm{NaHCO}_{3}$ and $50 \mu \mathrm{g}$ of Alexa Fluor $488 \mathrm{NHS}$ Ester (Thermo Fisher Scientific) was added. The cells were incubated at RT for $1 \mathrm{~h}$ while rotating. To remove excess dye, the cells were washed three times as above with $500 \mu \mathrm{L} \mathrm{CAB}$ media.

Isolation of stained S-layer

Staining was checked by sonicating the cells for $10 \mathrm{~min}$ in an ultrasonic bath. Afterwards, the cell debris was pelleted at $3400 \times \mathrm{xg}$ for $10 \mathrm{~min}$ at RT. SDS was added to a final concentration of $0.01 \%$ and the mixture was centrifuged again at $3400 \mathrm{xg}$ for $10 \mathrm{~min}$ at RT. The supernatant was divided into $2 \times 500 \mu \mathrm{L}$ and centrifuged at $190000 \mathrm{xg}$ for $1 \mathrm{~h}$ at $4{ }^{\circ} \mathrm{C}$. The resulting pellets were resuspended in $50 \mu \mathrm{l} 1 \mathrm{x}$ loading dye and in $5 \mu \mathrm{L} 1 \mathrm{x}$ PBS, $0.1 \%$ Triton-X 100 . Both pellets were incubated at $6{ }^{\circ} \mathrm{C}$, in a light-protected manner for $48 \mathrm{~h}$ and then mixed together. This was incubated for $21 / 2 \mathrm{~h}$ at $37^{\circ} \mathrm{C}$ and $10 \mu \mathrm{L}$ was used for an SDS-PAGE and detection of the fluorescence signal.

\section{S-layer isolation}

For S-layer isolation, $400 \mathrm{~mL}$ of $\mathrm{H} 26$ was grown at 45 ${ }^{\circ} \mathrm{C}$ to an $\mathrm{OD}_{600}$ of 1.37 . The cells were pelleted at $6200 \mathrm{xg}$ for $25 \mathrm{~min}$ at $4{ }^{\circ} \mathrm{C}$. The pellet was resuspended in $200 \mathrm{~mL} \mathrm{CA}$ media and $60 \mathrm{~mL}$ of $0.5 \mathrm{M}$ EDTA (pH 6.7) was added. Subsequently, the pellet was incubated at $37{ }^{\circ} \mathrm{C}$ while shaking for $30 \mathrm{~min}$. The spheroplasts were removed via centrifugation in an iterative manner at $3000 \mathrm{xg}$ for $15 \mathrm{~min}, 7000 \mathrm{xg}$ for $5 \mathrm{~min}$ and $13000 \mathrm{xg}$ for $10 \mathrm{~min}$. The supernatant was concentrated via Amicon $(\mathrm{MWCO}=50 \mathrm{kDa}$, Merck Millipore) to $500 \mu \mathrm{L}$. $16 \mu \mathrm{L}$ were used for an SDSPAGE and sent for Mass spectrometry.

\section{Fluorescence time-lapse microscopy}

For microscopy, $3 \mu \mathrm{L}$ of stained cells were pipetted on a $0.3 \%$ agarose pad consisting of agarose dissolved in $\mathrm{CAB}$ medium supplemented with $10 \mu \mathrm{g} / \mathrm{mL}$ uracil. Phase-contrast and fluorescence images were captured every 30 minutes for $16 \mathrm{~h}$ at $100 \mathrm{x}$ magnification at $\mathrm{pH} 3$ and GFP mode using a Zeiss Axio Observer 2.1 microscope equipped with a heated XL-5 2000 Incubator while running VisiVIEW ${ }^{\circledR}$ software. Images were analyzed using ImageJ, Fiji (Schindelin et al. 2012).

\section{Data Availability Statement}

The raw data will be made available by the authors, without undue reservation.

\section{Author contributions}

SS, PN, MB and SVA designed research. SS performed cryoET with technical help from FR. SS, SVA and MB analysed the tomograms and designed figures. $H W$ and $P N$ performed fluorescence microscopy. HW, PN, SS and SVA analysed the fluorescence microscopy data and designed figures. SS, MB and SVA wrote the manuscript. All authors read and reviewed the manuscript.

\section{Funding}

SS was supported by the Deutsche Forschungsgemeinschaft (German Research Foundation) under project no. 403222702-SFB 1381 and from the European Union's Horizon 2020 research and innovation program under grant agreement no. 686647. Mass spectrometry was performed with the help of the lab of Matthias Boll (supported by a grant from the German Research foundation (INST 39/995-1 FUGG). 


\section{Conflict of Interest}

The authors declare that the research was conducted in the absence of any commercial or financial relationships that could be construed as a potential conflict of interest.

\section{Acknowledgments}

We thank Dr Florian Rossmann and Paul Simpson for technical assistance with imaging $H$. volcanii for CryoET in the Imperial College Centre for Structural Biology Electron Microscopy Facility.

\section{References}

Ajon, Małgorzata et al. 2011. "UV-Inducible DNA Exchange in Hyperthermophilic Archaea Mediated by Type IV Pili." Molecular Microbiology 82(4): 807-17.

Allers, Thorsten. 2011. "Swapping Genes to Survive a New Role for Archaeal Type IV Pili." Molecular Microbiology 82(4): 789-91.

Allers, Thorsten, Hien Ping Ngo, Moshe Mevarech, and Robert G. Lloyd. 2004. "Development of Additional Selectable Markers for the Halophilic Archaeon Haloferax Volcanii Based on the LeuB and TrpA Genes." Applied and Environmental Microbiology 70(2): 943-53.

Amat, Fernando et al. 2008. "Markov Random Field Based Automatic Image Alignment for Electron Tomography." Journal of Structural Biology 161(3): 260-75.

Baidya, Amit K. et al. 2018. "Bacterial Nanotubes: A Conduit for Intercellular Molecular Trade." Current Opinion in Microbiology 42: 1-6.

Bertani, Giuseppe. 1999. "Transduction-like Gene Transfer in the Methanogen Methanococcus Voltae." Journal of Bacteriology 181(10): 2992-3002.

Carragher, Bridget et al. 2000. "Leginon: An Automated System for Acquisition of Images from Vitreous Ice Specimens." Journal of Structural Biology 132(1): 33-45.

Comolli, Luis R., and Jill F. Banfield. 2014. "InterSpecies Interconnections in Acid Mine Drainage Microbial Communities." Frontiers in Microbiology 5(JULY).

Dubey, Gyanendra P., and Sigal Ben-Yehuda. 2011. "Intercellular Nanotubes Mediate Bacterial Communication." Cell 144(4): 590-600.

Duggin, lain G. et al. 2015. "CetZ Tubulin-like Proteins Control Archaeal Cell Shape." Nature 519(7543): 36265.

Eiserling, F., A. Pushkin, M. Gingery, and Giuseppe
Bertani. 1999. "Bacteriophage-like Particles Associated with the Gene Transfer Agent of Methanococcus Voltae PS." Journal of General Virology 80(12): 3305-8.

Esquivel, Rianne N., and Mechthild Pohlschroder. 2014. "A Conserved Type IV Pilin Signal Peptide HDomain Is Critical for the Post-Translational Regulation of Flagella-Dependent Motility." Molecular Microbiology 93(3): 494-504.

Fröls, Sabrina et al. 2008. "UV-Inducible Cellular Aggregation of the Hyperthermophilic Archaeon Sulfolobus Solfataricus Is Mediated by Pili Formation." Molecular Microbiology 70(4): 938-52.

Fröls, Sabrina, Malcolm F. White, and Christa Schleper. 2009. "Reactions to UV Damage in the Model Archaeon Sulfolobus Solfataricus." Biochemical Society Transactions 37(1): 36-41.

Hernández, Javier $M$, and Benjamin Podbilewicz. 2017. "The Hallmarks of Cell-Cell Fusion." Development (Cambridge, England) 144(24): 448195.

Kessel, Martin, Ivo Wildhaber, Simone Cohen, and Wolfgang Baumeister. 1988. "Three-Dimensional Structure of the Regular Surface Glycoprotein Layer of Halobacterium Volcanii from the Dead Sea." The EMBO Journal 7(5): 1549-54.

Kremer, James R., David N. Mastronarde, and J. Richard McIntosh. 1996. "Computer Visualization of Three-Dimensional Image Data Using IMOD." Journal of Structural Biology 116(1): 71-76.

Kuwabara, Tomohiko et al. 2005. "Thermococcus Coalescens Sp. Nov., a Cell-Fusing Hyperthermophilic Archaeon from Suiyo Seamount." International Journal of Systematic and Evolutionary Microbiology 55(6): 2507-14.

Lang, Andrew S., Olga Zhaxybayeva, and J. Thomas Beatty. 2012. "Gene Transfer Agents: Phage-like Elements of Genetic Exchange." Nature Reviews Microbiology 10(7): 472-82.

Lipscomb, Gina L. et al. 2011. "Natural Competence in the Hyperthermophilic Archaeon Pyrococcus Furiosus Facilitates Genetic Manipulation: Construction of Markerless Deletions of Genes Encoding the Two Cytoplasmic Hydrogenases." Applied and Environmental Microbiology 77(7): 2232-38.

Mastronarde, David N. 1997. "Dual-Axis Tomography: An Approach with Alignment Methods That Preserve Resolution." In Journal of Structural Biology, Academic Press Inc., 343-52.

Meile, L., P. Abendschein, and T. Leisinger. 1990. "Transduction in the Archaebacterium Methanobacterium Thermoautotrophicum Marburg." Journal of Bacteriology 172(6): 3507-8. 
Mevarech, M., and R. Werczberger. 1985. "Genetic Transfer in Halobacterium Volcanii." Journal of Bacteriology 162(1): 461-62.

Naor, Adit et al. 2012. "Report Low Species Barriers in Halophilic Archaea and the Formation of Recombinant Hybrids." Current Biology 22: 1444-48.

Naor, Adit, and Uri Gophna. 2013. "Cell Fusion and Hybrids in Archaea: Prospects for Genome Shuffling and Accelerated Strain Development for Biotechnology." Bioengineered 4(3).

Prangishvili, David et al. 1998. "Conjugation in Archaea: Frequent Occurrence of Conjugative Plasmids in Sulfolobus." Plasmid 40(3): 190-202.

Quemin, Emmanuelle R.J. et al. 2016. "Eukaryotic-like Virus Budding in Archaea." mBio 7(5): 1439-55.

Rosenshine, Ilan, Ronen Tchelet, and Moshe Mevarech. 1989. "The Mechanism of DNA Transfer in the Mating System of an Archaebacterium." Science 245(4924): 1387-89.

Sára, Margit, and Uwe B. Sleytr. 2000. "S-Layer Proteins." Journal of Bacteriology 182(4): 859-68.

Sato, Takaaki, Toshiaki Fukui, Haruyuki Atomi, and Tadayuki Imanaka. 2005. "Improved and Versatile Transformation System Allowing Multiple Genetic Manipulations of the Hyperthermophilic Archaeon Thermococcus Kodakaraensis." Applied and Environmental Microbiology 71(7): 3889-99.

Schindelin, Johannes et al. 2012. "Fiji: An OpenSource Platform for Biological-Image Analysis." Nature Methods 9(7): 676-82.

Schleper, C. et al. 1995. "A Multicopy Plasmid of the Extremely Thermophilic Archaeon Sulfolobus Effects Its Transfer to Recipients by Mating." Journal of Bacteriology 177(15): 4417-26.

Schleper, C., K. Kubo, and W. Zillig. 1992. "The Particle SSV1 from the Extremely Thermophilic Archaeon Sulfolobus Is a Virus: Demonstration of Infectivity and of Transfection with Viral DNA." Proceedings of the National Academy of Sciences of the United States of America 89(16): 7645-49.

Segev, Nadav, Ori Avinoam, and Benjamin Podbilewicz. 2018. "Fusogens." Current Biology 28(8): R378-80.

Shalev, Yarden et al. 2017. "Cell Surface Glycosylation Is Required for Efficient Mating of Haloferax Volcanii." Frontiers in Microbiology 8: 1253.

Sleytr, Uwe B, Bernhard Schuster, Eva-Maria Egelseer, and Dietmar Pum. 2014. "S-Layers: Principles and Applications." FEMS microbiology reviews 38(5): 823-64.

Soler, Nicolas, Evelyne Marguet, Jean Marc
Verbavatz, and Patrick Forterre. 2008. "Virus-like Vesicles and Extracellular DNA Produced by Hyperthermophilic Archaea of the Order Thermococcales." Research in Microbiology 159(5): 390-99.

Stedman, K. M. et al. 2000. "PING Family of Conjugative Plasmids from the Extremely Thermophilic Archaeon Sulfolobus Islandicus: Insights into Recombination and Conjugation in Crenarchaeota." Journal of Bacteriology 182(24): 7014-20.

Sumper, M., E. Berg, R. Mengele, and I. Strobel. 1990. "Primary Structure and Glycosylation of the S-Layer Protein of Haloferax Volcanii." Journal of Bacteriology 172(12): 7111-18.

Turgeman-Grott, Israela et al. 2019. "Pervasive Acquisition of CRISPR Memory Driven by InterSpecies Mating of Archaea Can Limit Gene Transfer and Influence Speciation." Nature Microbiology 4(1): 177-86.

Wagner, Alexander, Rachel J. Whitaker, David J. Krause, Jan Hendrik Heilers, Marleen Van Wolferen, et al. 2017. "Mechanisms of Gene Flow in Archaea." Nature Reviews Microbiology 15(8): 492-501.

Wagner, Alexander, Rachel J. Whitaker, David J. Krause, Jan-Hendrik Heilers, Marleen van Wolferen, et al. 2017. "Mechanisms of Gene Flow in Archaea." Nature Reviews Microbiology 15(8): 492-501.

van Wolferen, Marleen et al. 2020. "Species-Specific Recognition of Sulfolobales Mediated by UV-Inducible Pili and S-Layer Glycosylation Patterns." mBio 11(2).

van Wolferen, Marleen, Małgorzata Ajon, Arnold J. M. Driessen, and Sonja-Verena Albers. 2013. "Molecular Analysis of the UV-Inducible Pili Operon from Sulfolobus Acidocaldarius." MicrobiologyOpen 2(6): 928-37.

Van Wolferen, Marleen, Alexander Wagner, Chris Van Der Does, and Sonja Verena Albers. 2016. "The Archaeal Ced System Imports DNA." Proceedings of the National Academy of Sciences of the United States of America 113(9): 2496-2501. 